\title{
IMPLEMENTASI PENGEMBANGAN \\ KEBERAGAMAAN PESERTA DIDIK DI SEKOLAH
}

(Studi Kasus SMA Negeri 1 Simpenan)

\author{
Anhar Munandar \\ STAI Pelabuhanratu \\ Email : anharmunandar222@gmail.com \\ Encep Solihutaufa \\ STAI Pelabuhanratu \\ Email : hutaufaencep717@gmail.com
}

\begin{abstract}
Abstrak
Tujuan dari penulisan makalah ini adalah untuk mendeskripsikan implementasi pengembangan keberagamaan peserta didik di SMA Negeri 1 Simpenan. Hasil observasi menunjukkan bahwa implementasi pengembangan keberagamaan peserta didik di SMA Negeri 1 Simpenan telah teraktualisasikan dengan baik dan terprogram, baik yang dilakukan oleh sekolah sebagai institusi pendidikan yang utuh dengan kebijaksanaan yang berkaitan dengan pengembangan keberagamaan di sekolah dan kegiatan masyarakat yang dilakukan oleh Rohis (Spiritual of Islam) sebagai salah satu ekstrakurikuler sekolah khusus menaungi kegiatan keagamaan lainnya. Kesuksesan ini bisa diraih karena usaha kepala sekolah dan dukungan seluruh komunitas sekolah dengan menunjukkan komitmen masing-masing yang saling terkait dan saling mendukung.
\end{abstract}

Kata Kunci : Keberagamaan, implementasi, Pengembangan

\section{Abstract}

The purpose of writing this paper is to describe the implementation of the development of student diversity in SMA Negeri 1 Simpenan. The results of the observations show that the implementation of the religious development of students at SMA Negeri 1 Simpenan has been well actualized and programmed, both carried out by the school as a complete educational institution with policies related to the development of religion in schools and community activities carried out by Rohis (Spiritual of Islam) as one of the extracurricular special schools that overshadow other religious activities. This success can be achieved because of the efforts of the principal and the support of the entire school community by showing their respective commitments that are interrelated and mutually supportive.

Keywords : Religius, Implementation, Develepoment

\section{PENDAHULUAN}

Mengapa di era globalisasi ini masalah dekadensi moral semakin meningkat, sehingga para orang tua semakin khawatir terhadap negatif dari globalisasi, yaitu semakin mudahnya nilai-nilai moral yang negatif mempengaruhi anak-anak didik baik melalui media cetak maupun elektronik, dan juga media online, bahkan kita saksikan langsung dalam kehidupan nyata sekitar kehidupan kita seperti tawuran antar geng, tawuran antar sekolah, mengkonsumsi miras atau narkoba, pemerkosaan, seks bebas, pencabulan, pencurian, dll. Dari beberapa contoh-contoh itu membuat kita sebagai insan pendidikan perihatin dengan masalah ini.

Masalah-masalah tersebut dapat diselesaikan dengan mengembangkan 
keberagamaan di Sekolah yang di lakukan oleh Guru PAI dengan cara:

1) Guru Pendidikan Agama Islam hendaknya menjalin kerjasama dengan aparat sekolah. Untuk mengembangkan budaya religius disekolah tentunya guru agama tidaklah bekerja sendirian. Dalam hal ini perlu adanya kerjasama antara guru-guru dan pihak aparat sekolah yang lain. Alasan mengapa hal ini sangat penting karena ketika guru matematika merasa hanya bertanggung jawab membina kemampuan berfikir, dan guru bidang studi olahraga dan kesehatan hanya merasa wajib membina kesehatan dan kekuatan fisik peserta didik dan guru agama merasa wajib menanamkan iman maka akibatnya pribadi peserta didik seolah-olah dapat dibagi-bagi secara tegas. Padahal pembentukan itu adalah pembentukan kepribadian yang mengandung tiga aspek besar, suatu pembentukan yang tidak saling terlepas satu dengan yang lainnya.

2) Guru Pendidikan Agama Islam hendaknya menjalin kerjasama dengan orang tua murid dan masyarakat. untuk menjaga keberlangsungan pendidikan agama Islam, dibutuhkan suatu penopang yang harus bekerja secara sinergis yakni keluarga, sekolah dan masyarakat. Urgensi kerjasama antara guru dengan orang tua peserta didik dikarenakan bahwa seorang anak menjalankan hampir seluruh kehidupannya di dalam lingkungan keluarga. Oleh karena itu keluarga sangat bertanggung jawab dalam mengajarkan anak tentang berbagai macam budaya religius. Keluarga juga bertanggung jawab untuk membekali anak dengan nilai-nilai pendidikan dan sosial yang baik.

3) Melalui penciptaan suasana keberagamaan di sekolah, Yang dimaksud dengan penciptaan suasana keberagamaan di sekolah adalah penciptaan suasana atau iklim kehidupan keagamaan Islam yang dampaknya ialah berkembangnya suatu pandangan hidup yang bernafas atau dijiwai oleh ajaran dan nilai-nilai agama Islam yang diwujudkan dalam sikap hidup serta keterampilan hidup oleh para warga sekolah. Menurut muhaimin keberagamaan dalam konteks pendidikan agama Islam ada yang bersifat vertikal dan ada yang bersifat horizontal. Penciptaan suasana kebergamaan yang bersifat vertikal dapat diwujudkan dalam kegiatan shalat berjamaah, puasa senin kamis, doa bersama ketika akan/telah meraih sukses tertentu, menegakkan komitmen dan loyalitas moral di sekolah dan lain-lain. Sedangkan penciptaaan suasana keberagamaan yang bersifat horizontal lebih mendudukkan sekolah sebagai institusi sosial, yang jika dilihat dari struktur hubungan antara manusianya dapat diklasifikasikan kedalam tiga hubungan, yaitu hubungan atasan bawahan, hubungan profesional, hubungan sederajat atau suka rela.

\section{METODOLOGI}

Penelitian ini merupakan jenis penelitian kualitatif. Pendekatan penelitian yang digunakan adalah pendekatan fenomenologis (arti keberadaan) yaitu cara pendekatan untuk memperoleh pengetahuan tentang sesuatu (objek) sebagaimana tampilnya dan menjadi pengalaman kesadaran kita Penggunaan pendekatan ini disesuaikan dengan tujuan pokok penelitian, yaitu mendeskripsikan implementasi pengembangan kebergamaan peserta didik di SMA Negeri 1 Simpenan

Adapun informan penelitian ini terdiri dari kepala sekolah, seluruh guru yang mengasuh mata pelajaran pendidikan agama Islam, beberapa orang guru selain guru pendidikan agama Islam, dan peserta didik yang ditentukan kemudian sesuai dengan kebutuhan dan tujuan penelitian. Informan tersebut dipilih berdasarkan tugas dan keterkaitan dengan tema penelitian, dengan menggunakan prinsip "snowball", yaitu penentuan informan penelitian yang semula jumlahnya sedikit, lama-lama menjadi besar. Hal ini ditujukan agar mendapatkan informasi yang optimal yakni sampai dengan datanya telah dianggap memadai atau datanya telah 
jenuh (tidak lagi diperoleh tambahan informasi baru yang berarti). Dengan menggunakan prinsip "snowball", maka informan penelitian ini juga meliputi karyawan dan pembina kegiatan keagamaan. Dalam rangka mengumpulkan seluruh data penelitian yang dibutuhkan dalam penelitian ini secara komprehensif, maka peneliti menggunakan tiga macam teknik pengumpulan data yaitu: wawancara, observasi dan dokumentasi.

Selanjutnya data yang telah terkumpul dianalisa secara kualitatif dengan mengikuti teknik analisa data yang dikemukakan oleh Miles dan Huberman, melalui tiga alur kegiatan yang dilaksanakan secara berurutan, yaitu; (1) reduksi data, (2) display data, dan (3) pengambilan kesimpulan/verifikasi dilakukan secara terus menerus selama proses penelitian berlangsung.

\section{HASIL DAN PEMBAHASAN}

Implementasi keberagamaan peserta didik yang dimaksudkan di sini adalah usaha yang direncanakan secara sistematis berupa bimbingan, pemberian informasi, pengawasan dan juga pengendalian untuk peningkatan kualitas peserta didik, khususnya dalam hal keagamaan dalam menciptakan sikap mental dan pengembangan potensi yang positif sehingga terbentuk keberagamaan yang baik pada diri peserta didik.

Berdasarkan pengamatan dan wawancara secara langsung dengan kepala sekolah, guru agama, pembina dan peserta didik, diketahui bahwa implementasi pengembangan keberagamaan yang dilaksanakan oleh SMA Negeri 1 Simpenan kabupaten Sukabumi adalah dengan melaksanakan berbagai kegiatan keagamaan yang wajib dilaksanakan dan diikuti oleh seluruh civitas akademika sekolah, khususnya peserta didik yang beragama Islam.

Kegiatan keagamaan yang dilaksanakan di sekolah dalam rangka mengimplementasikan pengembangan keberagamaan peserta didik dilaksanakan melalui dua kelompok pelaksana kegiatan keagamaan yaitu sekolah sebagai lembaga pendidikan yang utuh dengan kebijakankebijakan yang berkaitan dengan pengembangan budaya agama di komunitas sekolah dan Rohis (rohani Islam) sebagai jenis kegiatan ekstrakurikuler sekolah yang khusus menaungi kegiatan-kegiatan keagamaan lainnya.

Kegiatan keagamaan yang dilaksanakan sekolah sebagai lembaga yang berkomitmen untuk mengembangkan budaya agama di sekolah yang wajib diikuti oleh seluruh warga sekolah dilaksanakan dalam bentuk:

a. Majelis Ta'lim, dengan sub kegiatan; halaqoh, mentoring keagamaan, pengajian tilawatil Qur'an dan Tahfidz juz 30

b. Membaca al-Qur'an 15 menit sebelum jam pelajaran pertama dimulai

c. Membaca surah Yasin pada hari Jum'at

d. Sholat Dzuhur berjama'ah

e. Sholat Dhuha bersama

f. Pelaksanaan Perayaan Hari Besar Islam (PHBI)

g. Pesantren kilat bulan Ramadhan

h. Baksos (Bakti Sosial)

i. Lomba-lomba Islami

j. Bersalaman dengan guru sebelum masuk sekolah

k. Nasyid media dakwah lewat nada dan syair

1. Pakaian sekolah muslim-Muslimah, pada bulan Ramadhan dan wajib hari Jum'at

Dilihat dari waktu pelaksanaannya, kegiatan keagamaan tersebut ada yang dilaksanakan secara rutin baik secara harian, mingguan maupun tahunan. Kegiatan keagamaan yang dilaksanakan setiap hari antara lain membaca al-Qur'an selama 15 menit pada jam pelajaran pertama, bersalaman dengan guru sebelum masuk sekolah, sholat Zhuhur berjamaah dan sholat Dhuha. Mengingat keterbatasan daya tampung masjid SMA Negeri 1 Simpenan, khusus untuk sholat Zhuhur berjamaah dan sholat dhuha tidak diwajibkan kepada seluruh peserta didik untuk melaksanakannya melainkan sesuai kesadaran masing-masing, baik peserta didik maupun guru. Meskipun 
demikian ibadah sholat Zhuhur berjamaah tersebut setiap hari selalu dilaksanakan pada istirahat ke-2, dan biasanya dipimpin oleh salah seorang guru.

Dalam rangka pembinaan keberagamaan peserta didik SMA Negeri 1 Simpenan, selain melalui berbagai kegiatan keagamaan yang dilaksanakan oleh pihak sekolah yang wajib diikuti oleh seluruh peserta didik, sekolah ini juga melaksanakan kegiatan keagamaan melalui Rohis (Rohani Islam) yaitu organisasi ekstrakurikuler kepesertadidikan yang membidangi kegiatan keagamaan. Adapun kegiatan yang dilakukan rohis, yang wajib diikuti oleh peserta didik yang mengikuti organisasi Rohis SMA Negeri 1 Simpenan adalah sebagai berikut:

a. Mabit (malam bina iman dan taqwa) dengan kegiatan thausiyah, qiyamul lail, tadarus Qur'an, muhasabah, sholat berjama'ah, dan sebagainya

b. Rihlah, berkunjung ke tempat bersejarah dan yang lain dalam rangka $i$ 'tibar

c. Riadhoh dan Dauroh, kegiatan olah raga dan pelatihan dalam rangka pendalaman kompetensi organisasi dan keagamaan

d. Mukayyam, kegiatan berkemah untuk melatih kemandirian dengan kegiatan Islami

e. Kajian keislaman dan kajian kemuslimahan

f. Outbond

g. Kegiatan indoor

Berbagai kegiatan keagamaan tersebut di atas, baik yang dilaksanakan oleh sekolah sebagai lembaga pendidikan maupun yang dilaksanakan oleh Rohis sebagai organisasi ekstrakurikuler sekolah, diharapkan dapat menjadi jalan untuk menciptakan sikap mental dan berkembangnya potensi yang positif pada diri peserta didik, sehingga dapat memicu ketaatan peserta didik terhadap ajaran agama Islam dan dijadikan sebagai pedoman dalam kehidupan sehari-hari.

\section{PENUTUP}

Berdasarkan hasil pembahasan dalam penelitian ini, maka dapat disimpulkan bahwa pelaksanaan pembinaan keberagamaan peserta didik melalui pengembangan budaya agama di SMA 1 Simpenan telah berjalan dengan baik dan terprogram, baik yang dilaksanakan oleh sekolah sebagai lembaga pendidikan yang utuh dengan kebijakankebijakan yang berkaitan dengan pengembangan budaya agama di komunitas sekolah maupun kegiatan yang dilakukan oleh Rohis (Rohani Islam) sebagai jenis kegiatan ekstrakurikuler sekolah yang khusus menaungi kegiatan-kegiatan keagamaan lainnya. Keberhasilan ini dapat dicapai karena adanya upaya dari kepala sekolah dan dukungan seluruh warga sekolah dengan cara menunjukkan komitmennya masing-masing yang berlangsung secara bersama-sama dan saling mendukung satu sama lain. Pada akhirnya tujuan mengimplementasi pengembangan keberagamaan peserta didik mampu tercipta dengan baik.

\section{DAFTAR PUSTAKA}

Departemen Agama RI. 2005. AlQur'an dan Terjemahannya, Bandung: Diponegoro.

Moleong, Lexy J.2007. Metodologi Penelitian Kualitatif. Bandung: Remaja Rosda Karya.

Muhaimin dkk. 2001. Paradigma Pendidikan Islam; Upaya mengefektifkan Pendidikan Agama Islam di sekolah. Bnadung: Remaja Rosdakarya

Rahmat, Jalaluddin. 1989. "Penelitian Agama", dalam Taufiq Abdullah dan Rusli Karim (ed), Penelitian Agama: Sebuah Pengantar. Yogyakarta: Tiara Wacana.

Santrock, John W. 2007. Child Development, elevent edition. Diterjemahkan oleh Mila Rachmawati dan Anna Kuswanti, Perkembangan Anak. edisi ketujuh. Jakarta: Erlangga.

Sarwono, S.W, Psikologi Remaja, (Jakarta: PT Raja Grafindo Persada, 2003), 67

Stark, R. dan C.Y. Glock. 1968. American Piety: The Nature of Religious 
Anhar Munandar, dkk : Implementasi Pengembangan Keberagaman Peserta Didik di Sekolah : Studi Kasus SMA Negeri 1 Simpenan

Comitment, California: University of California Press.

Sugiyono, 2008. Metode Penelitian kuantitatife, Kualitatife, dan R \& D. Bandung:

ALFABETA 